\title{
Fungi Associated with Dieback and Pruning Wounds of Grapevines in South Africa
}

\author{
J.H.S. Ferreira ${ }^{1)}$, F.N. Matthee ${ }^{2)}$ and A.C. Thomas ${ }^{3)}$ \\ 1. Viticultural and Oenological Research Institute (VORI), Private Bag X5026, 7600 Stellenbosch, Republic of South Africa; \\ 2. University of the Western Cape, Private Bag X17, 7530 Bellville, Republic of South Africa; \\ 3. Banana Board, Private Bag X11208, 1200 Nelspruit, Republic of South Africa. \\ Submitted for publication: August 1989 \\ Accepted for publication: October 1989 \\ Key words: Dying arm, dieback, eutypiose grapevine, Eutypa lata
}

\begin{abstract}
Isolations were made from discoloured tissue of grapevines showing dieback symptoms in the winter rainfall region. Fifteen fungal species were isolated, of which Sphaeropsis sp. Fusarium oxysporum, Eutypa lata (anamorph: Libertella blepharis A.L. Smith), Pestalotia quepini and Botrytis cinerea could be designated as parasites. E. lata was the most probable cause of the dieback phenomenon. Additional isolates representing ten fungal genera were isolated from discoloured wood in spurs from visually healthy grapevines while organisms representing 14 genera were isolated from lesions in grapevines exhibiting dieback symptoms. Aspergillus sp. was more common in the healthy and marginal zones while Sphaeropsis sp. occurred more often in the healthy zone and Phylosticta sp. in the discoloured zone of pruning stubs. In lesions from vines with dieback symptoms, Alternaria alternata was isolated more regularly from the marginal zone between healthy and discoloured wood, while $E$. lata and Trichoderma harzianum were isolated more often from the older part of the lesion. A succession of fungi in the colonisation of pruning wounds and in dieback lesions is suggested.
\end{abstract}

Dieback of grapevine, caused by Eutypa lata (Pers: Fr.) Tul. syn. Eutypa armeniacae Hansf \& Carter (Anamorph: Libertella blepharis A.L. Smith) occurs worldwide (Petzoldt, Moller \& Sall, 1982). This disease is responsible for considerable loss in yield (Ferreira, 1988) and is one of the main causes of a shortened production life of vineyards (Moller \& Lehoczky, 1980). Ferreira (1988) found another Ascomycete, Cryptovalsa cf. ampelina to be abundant on one-year-old grape prunings and older dead wood. The anamorph stages of these two fungi cannot be distinguished morphologically. It is therefore possible that isolations from dieback vines can yield both fungi. In this paper however, isolates from dieback vines, which coincide morphologically with Libertella blepharis, were designated Eutypa lata.

According to Bolay \& Moller (1977), dieback of grapevines does not occur in dry areas and the rainfall must be higher than $300 \mathrm{~mm}$ for the formation of perithecia of the fungus on dead wood. The mean annual rainfall in the Western Cape Province ranges from $286 \mathrm{~mm}$ at Worcester to $1073 \mathrm{~mm}$ at Constantia.

Isolations from grapevines and apricot with dieback symptoms almost always yield pure cultures of $E$. lata (Bolay \& Moller, 1977; English \& Davis, 1978; Moller \& Kasimatis, 1978; Moller \& Lehoczky, 1980; Petzoldt, Moller \& Sall, 1981; Glawe, Dilley \& Moller, 1983). Some scientists, however, isolated additional fungi from dieback infected grapevines (Chiarappa, 1959; Marais, 1974; English \& Davis, 1978; Bisiach \& Minervini, 1985).

Pruning wounds in vines lead to discolouration of the underlying wood and are also the entry points for microorganisms. Evidence suggests that micro-organisms (bacteria and fungi) other than wood decay fungi also play a role in the discolouration of wood in trees (Shortle, 1979), while Blanchette \& Shaw (1978) claim that decay fungi can occur after or together with other micro-organisms. According to Shibo
(1967, 1972), Shortle, Tatter \& Rich (1971) and Shortle \& Cowling (1978) a succession of micro-organisms occurs after wounding of live trees, in which decay fungi follow bacteria and imperfect fungi which act as pioneer colonists.

The purpose of this study was to determine which fungi are associated with dieback and to establish whether different fungi were associated with different zones of discolouration in dieback lesions and in wounds initiated by pruning.

\section{MATERIALS AND METHODS} \section{ties \\ Isolation of fungi from dieback vines in different locali- \\ Samples of grapevines with dieback symptoms were col-} lected from 22 different localities throughout the winter rainfall region as indicated in Fig. 1. Four vines per locality

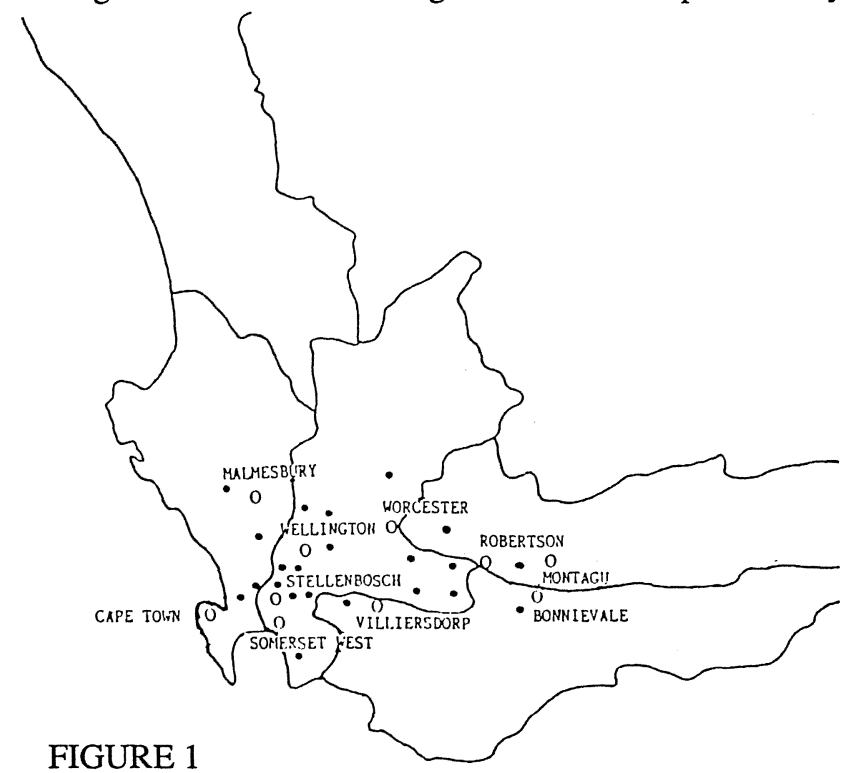

Localities where dieback vines were collected. 
showing typical dieback symptoms were cut off approximately $200 \mathrm{~mm}$ above soil level and sawn longitudinally to expose the affected wood. Forty wood chips of $5 \times 5 \times 3 \mathrm{~mm}$ (ten per vine) were taken from the dead wood, surface sterilised in $0,5 \%$ sodium hypochlorite and then placed on potato dextrose agar (PDA) in petri dishes. Initial isolations on PDA, malt agar and carrot agar indicated no difference in the fungal species isolated on these three media. Petri dish cultures were incubated under a combination of fluorescent and black light at $25^{\circ} \mathrm{C}$ with a $12 \mathrm{~h}$ photo period. After 5 days of incubation fungi were examined microscopically and tentatively identified on morphological characteristics. All fungi that did not sporulate were transferred to fresh medium and incubated as before. The formation of stylospores (anamorphal stage) were used to identify E. lata/C. cf ampelina (Ferreira, 1988). All species, except Acremonium sp and Phylosticta sp which could not be successfully recultured after storage on PDA in McCartney bottles, were subsequently sent to the Mycology unit, Plant Protection Research Institute, Pretoria, for confirmation of identity.

Isolation of fungi from one year old cane spurs

Twenty five-millimeters long wood samples (four replications of ten each) from spurs, each containing a one-year-old pruning wound, were collected randomly during the dormancy stage from a one hectare fourteen-year-old Cape Riesling (Crouchen blanc) vineyard at the VORI, Stellenbosch. Each spur was split longitudinally into quarters to expose discoloured and healthy wood. Three zones were distinguished visually: (i) discoloured, (ii) healthy and (iii) marginal wood (between healthy and discoloured wood). A wood chip ( 4 x 4 $\mathrm{x} 3 \mathrm{~mm}$ ) was cut from each of these zones allowing a border of not less than $2 \mathrm{~mm}$ between adjacent zones.

Following surface sterilisation in sodium hypochlorite containing $0,5 \%$ available chlorine, the four wood chips from each zone per spur were placed on malt extract agar (MA), containing choloromycetin $(500 \mathrm{mg} / \mathrm{l})$, in a petri dish.

After an incubation period of 7 days at $24^{\circ} \mathrm{C}$, fungal growth from each wood chip was examined microscopically and the fungi identified. Significant differences in the occurrence of fungi in the different zones were determined with Friedman's two-way analysis of variance by rank sums (Siegel, 1956).

Isolations of fungi from vines showing dieback symptoms

In the same vineyard as above vines with dieback symptoms were cut off approximately $100 \mathrm{~mm}$ above soil level. All shoots were removed and the vines split longitudinally with a bandsaw to expose discoloured wood. Four billets $3 \mathrm{~mm}$ thick (two from each half) were cut lengthwise. From the exposed surfaces, wood chips ( $5 \times 5 \times 3 \mathrm{~mm}$ ) were cut from three visually distinct zones: (i) the margin between healthy and discoloured wood of the extending lesion, (ii) the middle of the lesion, and (iii) from the back of the lesion (wound where infection originated). Wood chips were surface sterilised as described for pruning stubs. Four chips from each zone per billet were placed on MA in the same petri dish. One hundred and twenty-eight lesions, in some cases more than one lesion from the same vine, were sampled.

After incubation for 7 days at $24^{\circ} \mathrm{C}$, fungal growth was examined microscopically and the fungi identified. Signifi- cant differences in the occurrence of fungi in the different zones were determined as for cane spurs. Fungal species were stored on potato dextrose agar in McCartney bottles and those that could be successfully recultured at the end of the survey, were sent to the Mycology unit, Plant Protection Research Institute, Pretoria, to confirm original identification.

\section{RESULTS AND DISCUSSION}

Isolations of fungi from dieback vines in different localities

Eutypa lata was absent in only three of the localities sampled (Table 1). According to Petzoldt et al. (1981), 25 wood chips per vine are needed to isolate $E$. lata successfully from the border zone between healthy and discoloured wood, and if one of the wood pieces yielded $E$. lata, such a vine was regarded as being infected by the fungus. It is possible that $E$. lata would have been isolated from all the localities if a larger number of wood pieces had been used for isolation. Fifteen fungal species were isolated from dieback vines (Table 1).

Amongst the isolated fungi, Sphaeropsis sp, E. lata, Fusarium oxysporum, Phomopsis viticola, Botrytis cinerea and Pestalotia quepini, can be designated as parasitic fungi. The remaining fungi are assumed to be saprophytes. The occurrence of $F$. oxysporum, $P$. viticola, $B$. cinerea and $P$. quepini however, was too low to be considered as the cause of dieback. Although the Sphaeropsis sp. can also be considered parasitic, the ability of $E$. lata to form a toxin, which causes in vitro wilting of grapevine leaves and plantlets (Mauro et al. 1988), makes it the most probable pathogen for the dieback disease phenomenon.

Results in Table 1 further show that the occurrence of species differed between localities. This difference could be attributed to climatic factors or the age of the vines sampled. The general occurrence of Chenin blanc in South Africa may be the reason for the high number of dieback samples collected from this cultivar.

Isolations of fungi from one-year-old spurs

Ten fungal species were isolated from one-year-old spurs and all occurred in each of the three zones (Table 2). Population differences between the three zones were only significant in the case of three of the fungi isolated, namely Aspergillus sp., Phylosticta sp. and Sphaeropsis sp.

The significant higher occurrence of Aspergillus sp. in the healthy and marginal zones compared to the discoloured zone, and Sphaeropsis sp. in the healthy zone, indicated that these two species possibly act as pioneer organisms in the colonisation of pruning wounds. The concept of so-called "pioneer" organisms in the colonisation of wounds in trees is well documented (Shigo, 1967, 1972; Shigo \& Hillis, 1973; Shortle \& Cowling, 1978). Although only three fungal species were found to be significantly more common in any zone, the results indicate a possible succession of fungi in discolouration and decay of wood following wounding. In this regard it was established that Aspergillus sp. and Sphaeropsis $\mathrm{sp}$. were more common at the margin of the extending lesion while Phylosticta sp. was more common in the older part of the wound. This supports the results of Etheridge (1961), Good \& Nelson (1962), Shigo (1967, 1972), Tattar, Shortle \& Thich (1971) on succession of organisms in decay of wood after wounding. According to Shigo \& Hillis (1973) micro- 
TABLE 1.

Occurrence of fungi in dieback affected grapevines from different areas in the Western Cape.

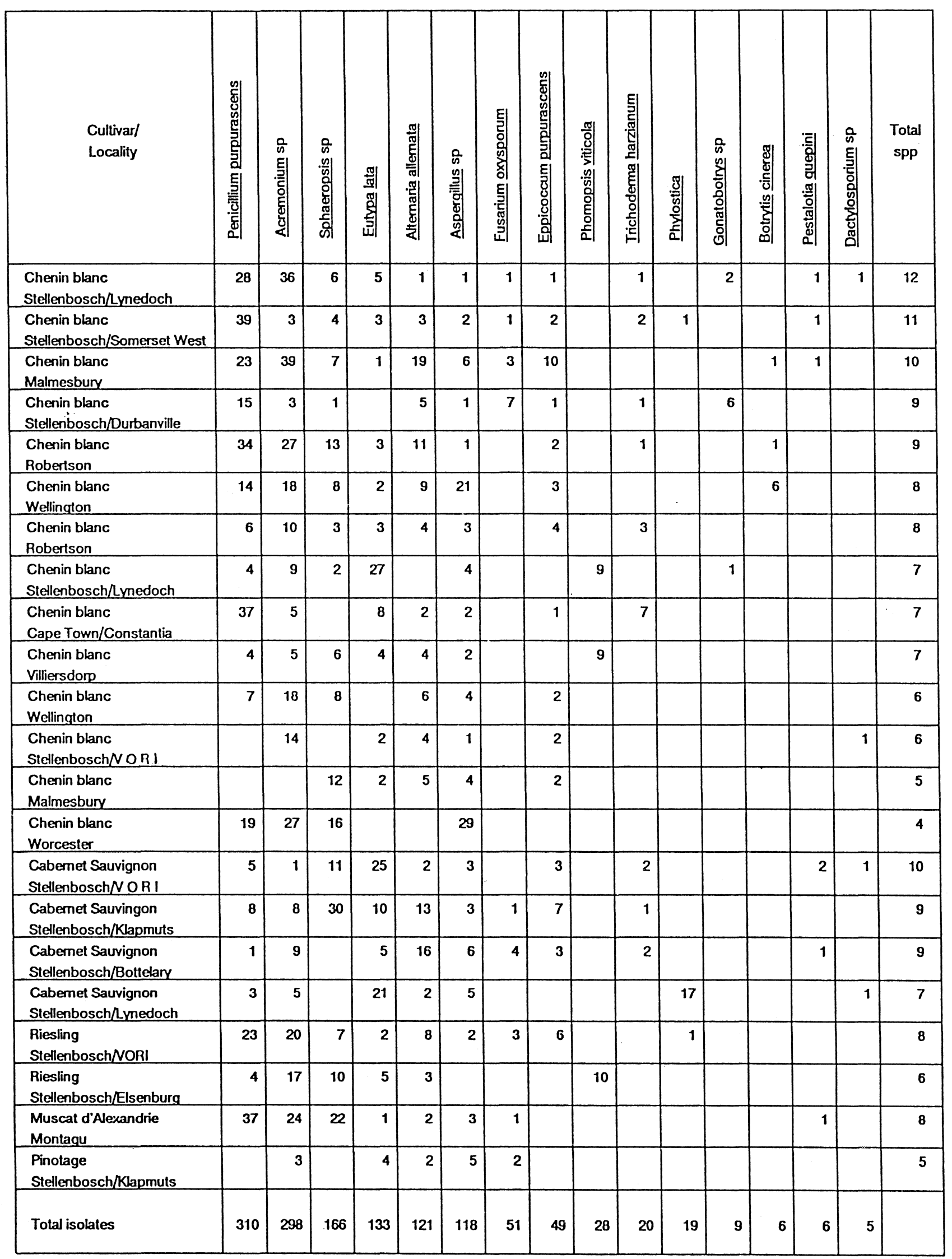

Figures represent number of isolates out of a possible total of 40.

S. Afr. J. Enol. Vitic., Vol. 10 No. 21989 
TABLE 2

Occurrence of fungi in three zones in one-year-old grapevine spurs.

\begin{tabular}{|c|c|c|c|c|c|c|c|c|c|c|}
\hline \multirow[b]{2}{*}{ Zone } & \multicolumn{10}{|c|}{ FUNGAL SPECIES } \\
\hline & 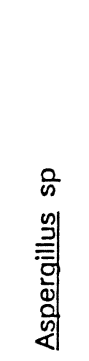 & 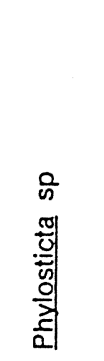 & 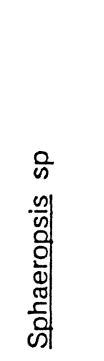 & 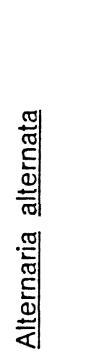 & 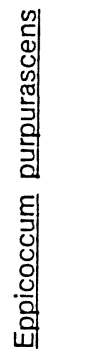 & 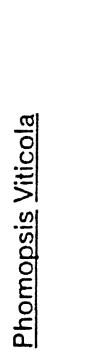 & 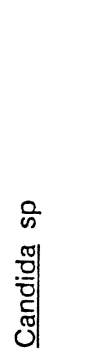 & 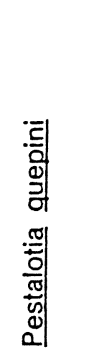 & 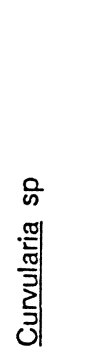 & 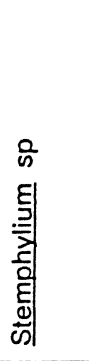 \\
\hline Healthy & $96,5 a$ & $66,5 a$ & $92,0 \mathrm{a}$ & $70,5 a$ & $69,5 a$ & $82,5 a$ & $85,0 a$ & $84,0 a$ & $84,0 a$ & $80,0 a$ \\
\hline Marginal & $88,5 a$ & $78,5 \mathrm{ab}$ & $78,0 \mathrm{ab}$ & $80,0 a$ & $87,0 a$ & $87,0 \mathrm{a}$ & $77,5 a$ & $79,0 \mathrm{a}$ & $79,0 a$ & $79,5 a$ \\
\hline Discoulored & $55,0 \mathrm{~b}$ & $95,0 \mathrm{~b}$ & $70,0 \mathrm{~b}$ & $89,5 a$ & $83,5 a$ & $71,5 a$ & $77,5 a$ & $77,1) \mathrm{a}$ & $77,0 \mathrm{a}$ & $80,0 a$ \\
\hline
\end{tabular}

Numbers represent rank sums. Numbers in columns followed by different letters differ significantly $(p \leq 0,05)$

organisms that inhabit wood in living trees have the greatest survival aơvantage when they infect wounds in a sequential manner by which pioneers alter the substrate to the advantage of the other micro-organisms that follow.
Isolations of fungi from vines showing dieback symptoms

Isolates representing fuuncen fungal species were obtained from lesions in dieback vines (Table 3). All species were present in each of the visually distinct zones. Of these species, only three were significantly more prevalent in one of the three zones.

TABLE 3

Occurrence of fungi in three zones from lesions in grape vines showing dieback symptoms

\begin{tabular}{|c|c|c|c|c|c|c|c|c|c|c|c|c|c|c|}
\hline \multicolumn{15}{|c|}{ FUNGAL SPECIES } \\
\hline Zone & 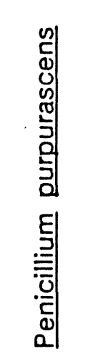 & 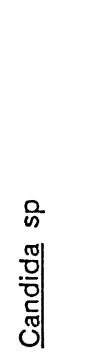 & 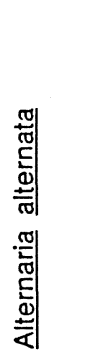 & 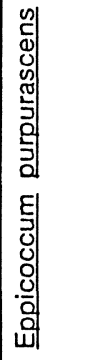 & 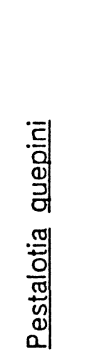 & 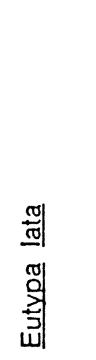 & $\begin{array}{l}0 \\
\overline{0} \\
\frac{0}{0} \\
0 \\
0 \\
0 \\
0 \\
0 \\
0 \\
0\end{array}$ & 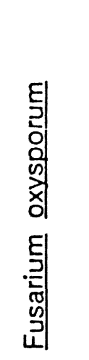 & 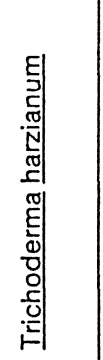 & 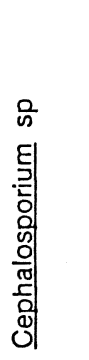 & 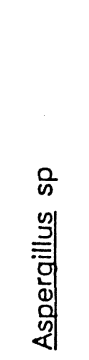 & $\begin{array}{l}0 \\
0 \\
0 \\
\vdots \\
0 \\
0 \\
0 \\
0 \\
0 \\
0 \\
0 \\
0 \\
0\end{array}$ & 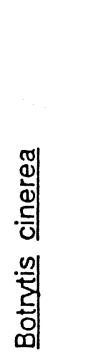 & 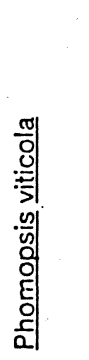 \\
\hline Marginal zone & $200,5 \mathrm{a}$ & $193,0 \mathrm{a}$ & $217,0 \mathrm{a}$ & 202,0a & $192,5 \mathrm{a}$ & $181,0 \mathrm{a}$ & $192,5 \mathrm{a}$ & $186,5 a$ & $188,0 \mathrm{ab}$ & $194,5 \mathrm{a}$ & $195,0 \mathrm{a}$ & $192,0 \mathrm{a}$ & $198,5 \mathrm{a}$ & $192,0 \mathrm{a}$ \\
\hline Middle & $193,0 \mathrm{a}$ & 193,0a & $187,0 \mathrm{~b}$ & $191,5 \mathrm{a}$ & $197,0 \mathrm{a}$ & 204,5ab & $185,0 \mathrm{a}$ & 192,5a & $180,5 \mathbf{a}$ & $187,0 \mathrm{a}$ & $190,5 \mathrm{a}$ & $192,0 \mathrm{a}$ & $191,0 \mathrm{a}$ & 195,0a \\
\hline Back & $184,0 \mathrm{a}$ & 191,5a & $173,5 \mathrm{~b}$ & $184,0 \mathrm{a}$ & $188,0 \mathrm{a}$ & $212,0 \mathrm{~b}$ & $200,0 a$ & $198,5 \mathrm{a}$ & $209,0 \mathrm{~b}$ & $195,0 \mathrm{a}$ & $192,0 \mathrm{a}$ & $193.5 \mathrm{a}$ & $188,0 \mathrm{a}$ & $190,5 \mathrm{a}$ \\
\hline
\end{tabular}

Numbers represent rank sums

Numbers in columns followed by different letters differ significantly $(\mathrm{p} \leq 0,05)$

S. Afr. J. Enol. Vitic., Vol. 10 No. 21989 
The significant occurrence of A. alternata sp. in the marginal zone between healthy and discoloured wood, while $E$. lata sp. and T. harzianum sp. were more prevelant in the oldest part of lesions in dieback vines, serves to demonstrate further a possible succession of fungi in the colonisation of vine pruning wounds. Eutypa lata and T. harzianum, however, never occurred together in the same lesion, possibly because of the antagonistic properties of the latter fungus (Dennis \& Webster, 1971a; 1971b). Several workers found that wound susceptibility to $E$. lata decreased with increasing wound age (Carter \& Moller, 1970; Carter \& Price, 1975; Ramos, Moller \& English, 1975; Moller \& Kasimatis, 1980; Petzoldt et al., 1981, 1982). This decrease in wound susceptibility is ascribed to rapid wound colonisation by other micro-organisms (Carter
\& Moller, 1970), which inhibit the growth of $E$. lata due to a possible competition for nutrients. Petzoldt et al (1981), however, ascribe this decrease in wound susceptibility to natural wound healing. From the present study it appears that fungi may colonise grapevine wood in a successive manner and it is possible that some of the fast growing early colonisers can inhibit the growth of $E$. lata as suggested by Carter \& Moller (1970). Another possibility is that fresh wounds cannot readily be invaded by $E$. lata and that the early invaders predispose the wood for later growth by $E$. lata and other wood invaders. This succession of micro-organisms will be ever changing depending on age of the wound, nutritional status of the wood and environmental factors.

\section{LITERATURE CITED}

BLANCHETTE, R.A. \& SHAW, C.G., 1978. Association among bacteria, yeast and bacidiomycete during wood decay. Phytopathology 68, 631-637.

BOLAY, A. \& MOLLER, W. J, 1977. Eutypa armeniacae Hansf. \& Carter. Agent d'un grave deperissement de vignes en production. Rev. suisse Vitic. Arboric. Hortic. 9 , 241-251.

BISIACH, M. \& MINERVINI, G., 1985. Libertella blepharis A.L. Smith and other fungi associated with an atypical syndrome on grapevine. Vignevini, Bologna 12, 31-35.

CARTER, M.V. \& MOLLER, W.J., 1970. Duration of susceptibility of apricot pruning wounds to infection by Eutypa armeniacae. Aust.J. Agric. Res. 11, 915-920.

CARTER, M.V. \& PRICE, T.V., 1975. Biological control of Eutypa armeniacae. A comparison of chemical, biological and integrated control. Aust. J. agric. Res. 26, 537-543.

CHIARAPPA, L., 1959. Wood decay of the grapevine and its relationship with black measles disease. Phytopathology 49, 510-519.

DENNIS, C. \& WEBSTER, J., 1971(a). Antagonistic properties of species-groups of Trichoderma. I. Production of nonvolatile antibiotics. Trans. Br. Mycol. Soc. 57, 25-39.

DENNIS, C. \& WEBSTER, J., 1971(b). Antagonistic properties of species-groups of Trichoderma. II. Production of volatile antibiotics. Trans. Br. Mycol. Soc. 57, 4148.

ENGLISH, H. \& DAVIS, H.R., 1978. Eutypa armeniacae in apricot: pathogenesis and induction of xylem soft rot. Hilgardia 46, 193-204.

ETHERIDGE, D.E., 1961. Factors affecting branch infection in aspen. Can. J. Bot. 39, 798-816.

FERREIRA, J.H.S. 1988. Dieback of grapevines in South Africa. PhD thesis, University of the Western Cape, Private Bag X117, 7530 Bellville.

GLAWE, D.A., DILLEY, M.A. \& MOLLER, W.J., 1983. Isolations and identification of Eutypa armeniacae from Malus domestica in Washington State. Mycotaxon 18, 315-318.

GOOD, H.M. \& NELSON, J.I., 1962. Fungi associated with Fomes ignarius in living poplar trees and their probable significance in decay. Can. J. Bot. 40, 615-624.

MARAIS, P.G. 1974. Tandpyn by wingerd. Wynboer 4, 29.

MAURO, M.C., VAILLANT, P., TEY-RULH, P., MATTHIEU, Y. \& FALLOT J., 1988. In vitro study of the relationship between Vitis vinifera and Eutypa lata (pers.:
Fr.) Tul. I. Demonstration of toxic compounds secreted by the fungus. Am.J.Enol. Vitic. 39, 200-204.

MOLLER, W.J. \& KASIMATIS, A.N., 1978. Dieback of grapevines caused by Eutypa armeniacae Pl. Dis. Reptr. 62, 254-258.

MOLLER, W.J. \& KASIMATIS, A.N., 1980. Protection of grapevine pruning wounds from Eutypa dieback, Plant Dis. 64, 278-280.

MOLLER, W.J. \& LEHOCZKY, J., 1980. The occurrence of Eutypa dieback of grapevine in Hungary. Phytopath. Z. 99, 116-125.

PETZOLDT, C.H., MOLLER, W.J.\& SALL, M.A., 1981. Eytypa dieback of grapevine: seasonal differences in infection and duration of susceptibility of pruning wounds. Phytopathology 71, 540-543.

PETZOLDT, C.H., MOLLER, W.J. \& SALL, M.A., 1982. Grapevines show seasonal differences in susceptibility to Eutypa. Calif. Agric. March-April, 4-5.

RAMOS, D.E., MOLLER, W.J. \& ENGLISH, H., 1975. Production and dispersal of ascospores of Eutypa Armeniacae in California. Phytopathology 65, 1364-1371. SHIGO, A.L., 1967. Succession of organisms in discoloration and decay of wood. Int. Rev. For. Res. 2, 238-299.

SHIGO, A.L., 1972. Succession of micro-organisms and patterns of discoloration and decay after wounding in red oak and white oak. Phytopathology 62, 256-259.

SHIGO, A.L. \& HILLIS, W.E., 1973. Heartwood, discolored wood and micro-organisms in living trees. Ann. Rev. Phytopathol. 11, 197-222.

SIEGEL, S., 1956. Friedman's two way analysis of variance by ranks. In: Harlow, H.F. (ed.) Nonparametric statistics for the behavioural science. McGraw-Hill International Book Company, New York, pp. 166-173.

SHORTLE, W.C., 1979. Compartmentalisation of decay in red maple and hybrid poplar trees. Phytopathology 69, 410-413.

SHORTLE, W.C. \& COWLING, E.D., 1978. Interaction of live sapwood and fungi commonly found in discolored wood and decay wood. Phytopathology 68, 617623.

SHORTLE, W.C., TATTAR, J.A. \& RICH, A.C., 1971. Effect of some phenolic compounds on the growth of Phialophora melinii and Fomes connatus. Phytopathology 61, 552-555.

TATTAR, T.A., SHORTLE, W.C. \& RICH, A.E., 1971. Sequence of micro-organisms and changes in constituents associated with discoloration and decay of sugar maple infected with Fomes connatus. Phytopathology 61, 556-558. 